Article

\title{
Economic and Technical Considerations in Pursuing Green Building Certification: A Case Study from Iran
}

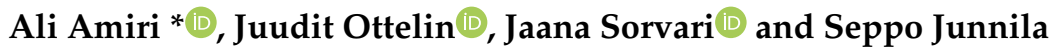 \\ Department of Built Environment/School of Engineering, Aalto University, 00076 Espoo, Finland; \\ juudit.ottelin@aalto.fi (J.O.); jaana.sorvari@aalto.fi (J.S.); seppo.junnila@aalto.fi (S.J.) \\ * Correspondence: ali.amiri@aalto.fi; Tel.: +358-403211200
}

Received: 11 December 2019; Accepted: 15 January 2020; Published: 19 January 2020

check for updates

\begin{abstract}
Buildings use $30-40 \%$ of all energy resources and are thus the main consumers in modern society. Moreover, buildings require a vast amount of different raw materials. During the last two decades, several green building certifications have been created in order to consider the social, economic, and environmental aspects of the sustainability of buildings. One of the most famous and widely used of these certifications is Leadership in Energy and Environmental Design (LEED). So far, the use of LEED has concentrated in the US and other developed countries. One reason that restricts the use of this point-based system certification in developing countries is the limited data about its costs. In this study, the extra cost of the certification process were evaluated, besides the changes needed in the design of the building to reach the points required by LEED. At the first stage, the number of points the case study earns in its current format (Scenario 1) were assessed, then the cost difference of getting either the Certified (Scenario 2) or Silver (Scenario 3) level LEED certification for the building was studied. It was found that besides some technical considerations, filling the criteria of the Certified and Silver level increases the total costs of construction by $3.4 \%$ and $5.9 \%$, respectively. Further improvement of the building's energy efficiency would enable the attainment of a higher-level certification. The results of the study could help to promote the use of green building certifications in Western Asia.
\end{abstract}

Keywords: leadership in energy and environmental design; LEED; sustainable construction; cost; Iran

\section{Introduction}

\subsection{Background}

The willingness to consider sustainability aspects in the construction of buildings has increased during recent decades [1-3]. As the latest Intergovernmental Panel on Climate Change (IPCC) report revealed, restricting climate change to $1.5^{\circ} \mathrm{C}$ degrees is going to be challenging, since global greenhouse gas emissions show no downturn [4]. Similarly, global material consumption keeps increasing [5,6]. In addition, the continuous rise in energy consumption makes it necessary to construct energy-efficient and environmentally friendly buildings $[7,8]$.

The construction sector causes almost half of the greenhouse gas emissions and uses nearly $40 \%$ of the natural resources worldwide [9]. It plays a significant role in countries' economies and provides job opportunities [10]. The effect of construction on the environment becomes particularly important in developing countries, which use a large amount of resources for their construction activities [11]. Buildings, as one of the construction activities, consume the main portion of energy produced all over the world [12-14]. According to the building sector, in the UK and US, buildings use $45 \%$ and $42 \%$ of the entire produced energy, respectively [15], while this amount is 30\% in China [16]. Buildings' energy consumption in Iran, as the second largest country in the Middle East, is $41.9 \%$ of the total energy use, 
which is produced from sources of natural gas $(66 \%)$, petroleum (20\%), electricity $(2.5 \%)$, and other sources $(1.5 \%)$ [17]. Due to the high energy consumption and material use by buildings, plans and rules are needed to minimize their environmental impact and make them green [18-20].

The understanding of what green building means in practice varies in different parts of the world. In some countries, residents might consider their building green if there is onsite energy production. In another location, using recycled materials might be considered green construction, as it has a lower impact on the environment. There are different definitions for green buildings. Yudelson [21] defines a green building as: "A high-performance property that considers and reduces its impact on the environment and human health". Alternatively, Kibert [22] defines green buildings as: "Healthy facilities designed and built in a resource-efficient manner, using ecologically based principles". Hence, there is a need to have a clear, uniform definition for green buildings worldwide.

This has brought about the development of different green building certification systems [23-27]. The British Building Research Establishment Environmental Assessment Method (BREEAM) is the first one of these, while the most commonly used system is Leadership in Energy and Environmental Design (LEED) of the U.S. Green Building Council (USGBC), released in 1998. The LEED certification is based on points and includes four levels, namely Certified (40-49 points), Silver (50-59 points), Gold (60-79 points), and Platinum ( $80+$ points).

LEED is currently the most famous building certification system and it is used all over the world [28-32]. The USGBC [33] describes LEED as follows:

LEED, or Leadership in Energy and Environmental Design, is the most widely used green building rating system in the world. Available for virtually all building, community and home project types, LEED provides a framework to create healthy, highly efficient and cost-saving green buildings. LEED certification is a globally recognized symbol of sustainability achievement.

Green certifications can bring economic benefits for property owners and tenants. In the literature, the economic benefits of green-certified buildings have been divided into four categories: 1 . lower operation costs because of saving in energy, e.g., electricity; 2 . lower maintenance costs as a result of functional testing of all energy systems before occupation; 3 . increased value of the building, which directly correlates with energy saving; and 4 . tax benefits offered by the government or local authorities [34].

Furthermore, Burnett [35] stated higher quality places for working and living as social benefits of green buildings. Using maximum natural light in green buildings makes them more attractive than conventional ones [19]. Green buildings limit the use of fossil fuels and replace them with renewable sources of energy, while improving the reuse and recycling of materials instead of using new materials [36]. Thus, green buildings reduce the negative environmental impacts of the building sector [37].

However, the LEED certification might result in additional expenses in building projects [36,38-42]. Different studies have concluded that the construction of LEED-certified buildings will result in extra costs. On the other hand, some researchers believe that the construction of LEED-certified buildings is possible without any extra cost $[43,44]$. Hence, it is difficult to draw definite conclusions on the cost effect, especially when comparing buildings in different locations of the world, including developed or developing countries, with different construction regulations. In addition, the version of LEED and level to be pursued (Certified, Silver, Gold, and Platinum) plays a significant role.

\subsection{Literature Review on the Costs of LEED}

The first version of LEED, LEED v1, was originally developed as a building rating system just for new construction (NC) [45]. In 2001, the second version, LEED NC v2, was published, followed by an update, LEED NC v2.2, in 2005. The most widely used version, LEED v3, published in 2009, included a collection of rating systems for construction, design, and operation. It was suitable for 
different types of buildings. LEED v4 was released in late 2013 with an update as the current version, LEED V4.1, in 2019. As the most widely used version is v3 or 2009, a large number of LEED-certified buildings are labeled with this version. Considering cost as one of the main issues of getting a LEED certification, several previous studies have compared the cost difference between LEED-certified and conventional buildings.

She et al. [40] stated that in order to construct buildings sustainably in China and to get a LEED certification v3, a premium cost of $4.5 \%$ to $11 \%$ is needed. A study conducted in California showed the extra cost from different levels of LEED certification v2 as 0-2.5\% for Certified, $0-3.3 \%$ for Silver, $0.3-5 \%$ for Gold, and $4.5-8.5 \%$ for Platinum level certified buildings [46]. In this research, different case buildings, including $\mathrm{K}-12$ public schools, research laboratories, public libraries, and multi-family affordable housing, were studied.

Kats et al. [39] analyzed the cost of 33 LEED-certified v2 buildings in California to find out the cost difference of certified and non-certified buildings. They found out that the extra cost of the studied LEED-certified buildings was $1.84 \%$ on average. While they considered the cost difference small, they concluded that the benefits of LEED-certified buildings exceed the additional costs and can be compensated in two or three years. The benefits include lower maintenance and operation costs, reduced energy, improved health of occupants, and enhanced productivity.

According to Fuerst and Franz [41], additional expenses of $2 \%$ to $10 \%$ are expected when a buildings is certified with the LEED system. Their study was focused on cost differences. besides sales and rental price premiums, of eco-friendly buildings in US. They found no significant change in the average selling time of eco-certified buildings. In addition, no noticeable advantages of rent for certified buildings with lower levels of certification were seen.

In 2017, Uğur and Leblebici [47] analyzed the cost of two LEED-certified v3 buildings in Turkey, one with a Gold- and the other a Platinum-level certification, and ended up with $7.43 \%$ and $9.43 \%$ extra costs caused by certification compared to non-certified buildings. The reduction in annual energy consumption cost of studied buildings was determined to be $31 \%$ and $40 \%$, while the payback period for additional construction cost was calculated to be 0.41 and 2.56 years.

On the other hand, some researchers have ended up with different results and reported no cost difference between green construction and traditional construction. For example, in a widely cited article, Matthiessen and Morris [43] compared the actual costs of 45 LEED-certified v2 buildings with 93 non-certified similar buildings using a t-test in the US. They concluded that there is no significant difference in terms of costs between these two groups of buildings.

An analysis of extra cost comparing two LEED-certified v3 bank buildings with eight non-certified ones located in Colorado was done by Mapp et al. [48], which showed an insignificant cost difference. The study evaluated total building costs, square footage costs, hard costs, and soft cost. In another study, Matthiessen and Morris [44] confirmed no cost difference in their study of 221 buildings, of which 83 were pursuing a LEED certification v2. Their study included different types of buildings in the US, such as office buildings, libraries, hospitals, residential apartments, student houses, theaters, and sport facilities.

It should be noted that LEED certification has changed significantly from its initial version to LEED v4, which may explain some of the differences in the findings on the costs of LEED certification. The majority of the previous research, including the above-mentioned studies, has focused on the cost of buildings which have earned a certification based on LEED v2 or v3. According to literature, studies conducted on $v 4$ LEED-certified buildings are rare because this version was announced only in late 2013.

Previous studies have mainly evaluated the cost difference of the buildings that already have LEED, not those that do not have any certification in their current format and are willing to predict the extra cost of getting the certification. Therefore, further studies on LEED-certified buildings, especially with $\mathrm{v} 4$, are necessary in order to evaluate the need for technical changes in addition to the costs of getting a building LEED-certified. 
Another important issue is that the majority of the existing LEED-certified buildings are located in the US and Canada [49]. Several studies have been conducted in China, as a developing country, where the number of LEED-certified buildings is increasing. However, it would be important to provide case studies for developing countries, where LEED is not yet popular. Currently, there are more than 94,000 building projects participating in LEED globally [29]. None of these projects are located in Iran. One possible reason for this is the lack of knowledge on the costs of LEED in Iran, while other reasons might be people's inadequate environmental awareness, low energy and water prices, and the shortage of regulations. Relying on the case studies of developed countries and China and following their approaches might not be completely helpful for developing countries with different circumstances.

\subsection{Aim of This Study}

As described above, there is a lack of case studies on the costs of LEED in other developing countries aside from China. Furthermore, the majority of the existing literature is focused on the costs of the previous versions of LEED, instead of the latest version, LEED v4. Therefore, the aim of this study is to provide a timely case study on the costs of LEED in a developing country, where the uncertainty of the costs may well be one of the main barriers for pursuing green certificates for buildings. This study evaluates the extra costs of the certification process, taking into account the changes in design of the building to reach the points required by LEED v4 by using a real case building located in Karaj (Iran). Currently, this building has no green building certification of any kind. In addition to studying the cost difference, this study provides technical details for design and construction phases, which enable the attainment of a LEED certificate.

\section{Materials and Methods}

\subsection{Case Building}

Typical buildings in Iran are five to six floors (one ground floor plus four to five floors) in most cities. For these kind of buildings it is common to use reinforced concrete for the structure, as the use of a steel structure will result in at least $20 \%$ extra cost for structure [50]. The case building was selected as it represents a customary building in Iran. Regarding the location, the city of Karaj, it is necessary to mention that construction costs in this city are very similar to other cities in Iran, except the capital city (Tehran), where costs are higher because of different conditions, e.g., higher salaries.

Considering the above-mentioned facts, the selected case study, named Ana Building, comprises a six-floor building (Table 1) located in region two of Karaj city (Iran). The ground floor is used for parking and five other floors contain private residential units (three units in each floor). The construction of the building began in 2017 and it was finished in 2019. The structure, including foundation, columns, beams, and slabs, is made of reinforced concrete. The inner and outer walls are made of clay brick. The inner walls are covered by a mix of gypsum and clay, while the outer walls are covered by cement lining.

The main source of heating is natural gas, while electricity is used for cooling purposes. In Iran, the energy used for heating, cooling, and hot water production is $83 \%$ of the entire energy use, while appliances and lighting account for $8 \%$ and $9 \%$, respectively [17]. In the case building, hot water used for both the heating of the building and daily use is produced by a water-mounted heater using natural gas as the source of energy. An electric evaporator cooler is applied for cooling purposes. For the façade, travertine stone has been used and double-glazed windows with standard Unplasticized Polyvinyl Chloride (uPVC) have been installed. The building is equipped with automatic lighting control systems for the outdoor and common areas, and it has normal switchable lighting for indoor spaces. 
Table 1. Building's features and construction costs.

\begin{tabular}{ll}
\hline \multicolumn{1}{c}{ Building Information } & \\
\hline Type of building & Residential \\
Type of ownership & Private \\
Status & New construction \\
Number of floors & $5+1$ \\
Number of units & 15 \\
Construction start date & October 2017 \\
Construction end date & March 2019 \\
Land area & $660 \mathrm{~m}^{2}$ \\
Building coverage & $451 \mathrm{~m}^{2}$ \\
Gross area (total construction) & $2740 \mathrm{~m}^{2}$ \\
Height & $21 \mathrm{~m}^{2}$ \\
Total construction cost & $\$ 527,024$ \\
\hline
\end{tabular}

\subsection{LEED Certification}

In LEED v4, 110 points are allocated to nine categories: Integrative Process (IP), Location and Transportation (LT), Sustainable Sites (SS), Water Efficiency (WE), Energy and Atmosphere (EA), Material and Resources (MR), Indoor Environment Quality (IQ), Innovation (IN), and Regional Priority (RP). Each category includes several credits and the potential maximum number of points have been defined for each credit (Table 2). Some of the categories have prerequisites, which need to be fulfilled-no points are allocated for prerequisites. Table 2 shows the number of credits in each category and the number of points allocated for each credit.

Table 2. Categories, credits, prerequisites, and available points in Leadership in Energy and Environmental Design (LEED) v4.

\begin{tabular}{lcccc}
\hline \multicolumn{1}{c}{ Categories } & Prerequisites & Credits & Available Points & Share \% \\
\hline Integrative Process (IP) & - & 1 & 1 & 0.9 \\
Location and Transportation (LT) & - & 7 & 16 & 14.6 \\
Sustainable Sites (SS) & 1 & 6 & 10 & 9.1 \\
Water Efficiency (WE) & 3 & 4 & 11 & 10 \\
Energy and Atmosphere (EA) & 4 & 7 & 33 & 30 \\
Materials and Resources (MR) & 2 & 5 & 13 & 11.8 \\
Indoor Environmental Quality (IQ) & 2 & 9 & 16 & 14.5 \\
Innovation (IN) & - & 2 & 6 & 5.5 \\
Regional Priority (RP) & - & 4 & 4 & 3.6 \\
\hline \multicolumn{1}{c}{ Total } & $\mathbf{1 2}$ & $\mathbf{4 5}$ & $\mathbf{1 1 0}$ & $\mathbf{1 0 0}$ \\
\hline
\end{tabular}

The format of 110 points was first used in LEED v3, while it was 69 points in the previous version. In LEED v2, 69 points were given to the six categories of SS (including both SS and LT), EA, WE, IQ, MR, and IN. One extra category of RP was added in LEED v3, which increased the number of categories to seven. Besides adding the IP category in LEED v4, USGBC decided to separate the SS category used in the previous versions into two categories, including SS and LT. In LEED v4, 16 points are given to LT and 10 to the SS category, while 26 points were given to SS category in LEED v3.

\subsection{Allocation of Points}

Firstly, the LEED categories and credits had to be examined, and the points that were already earned by the selected building defined (Table 3). The next stage was to find out the potential points that the building was eligible to earn (Table 3 ) in order to attain the points needed for the LEED level being pursued (41 points for LEED Certified and 51 for LEED Silver). The construction experts in Rah 
Rizan Fardis Co. (a construction company) were consulted at this point in order to determine the most feasible credits.

Table 3. Allocation of points for the studied building ( $\mathrm{s}$ fulfill $=$ should fulfill).

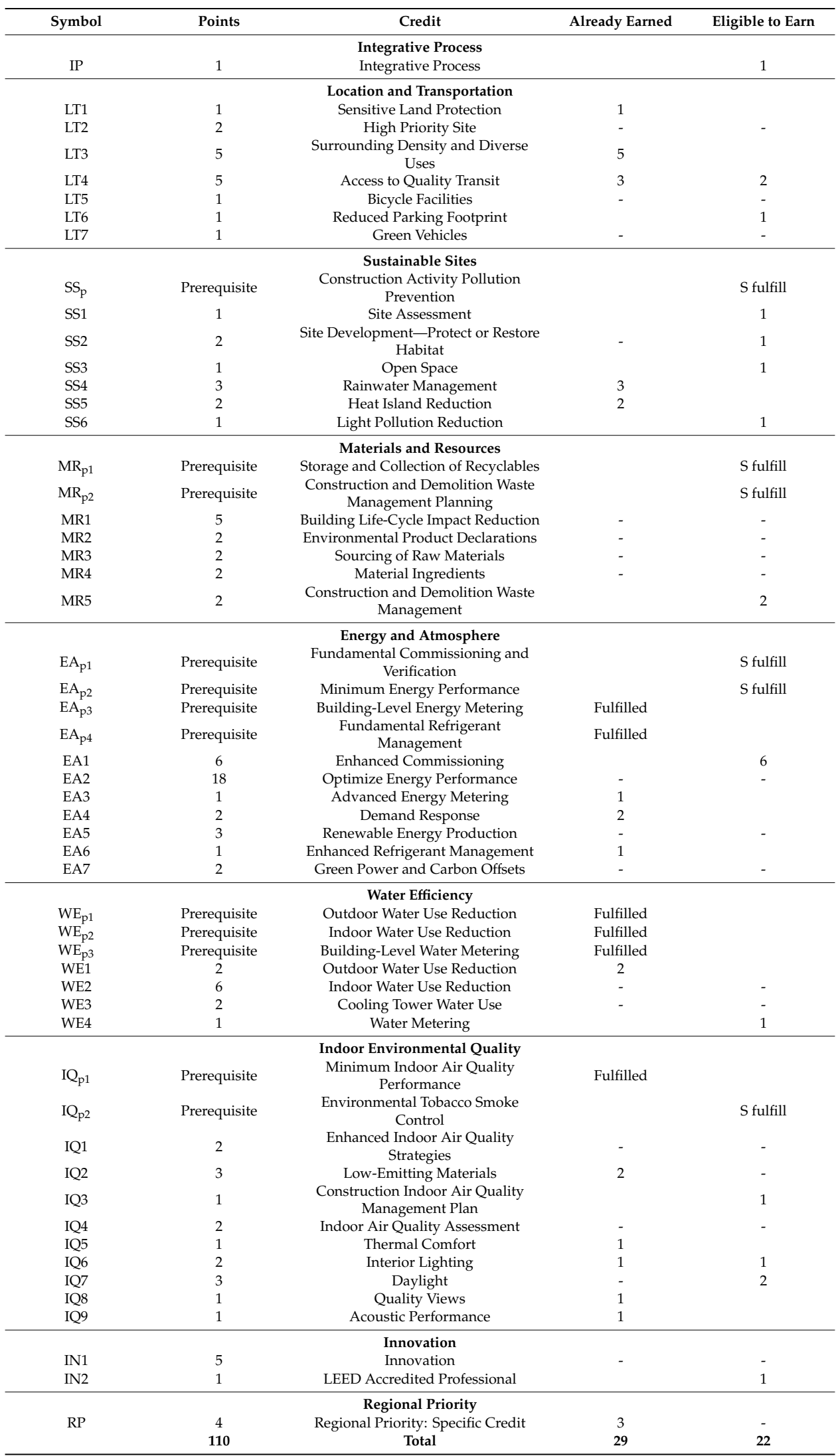


As described above, there are categories in LEED, such as Location and Transportation, which have several credits. Each credit might have 1 to maximum of 18 points. As an example, the Sensitive Land Protection (LT1) credit has one point that the case building obtained in its current format and therefore in Table 3, the already earned column includes number one, while the eligible to earn column is empty. A hash sign denotes situations where earning a point was not possible, e.g., in the case of the High Priority Site (LT2) credit.

At the following stage, the construction costs were estimated, besides the technical considerations (Table 4) needed in order to get the points required for the specified certification level. As shown in Table 4, some of the required actions cause extra costs while some changes are reachable without any added cost and by just some technical modifications implemented in the design phase. Credits in the categories $\mathrm{EA}_{\mathrm{p} 2}$ and IQ7 are interrelated with IP. Finally, based on the requirements of the Certified and Silver level, the cheapest combination of required actions was identified (Table 4). The original prices were in Iranian Rial (IRR), which was converted to US dollar (\$) with the exchange rate of $\$ 1=42,000$ IRR.

Table 4. Available points attainable by extra economic input or technical modifications.

\begin{tabular}{|c|c|c|}
\hline & Action Required & Changes \\
\hline IP & Conduct energy-related and water-related modeling, including daylight simulation & $\$ 6850.00$ \\
\hline LT4 & Access to Metro will launch in less than 18 months & Public action \\
\hline LT6 & Reduce prepared parking space to the minimum required & Technical consideration \\
\hline $\mathrm{SS}_{\mathrm{p}}$ & Prepare plastic coverage of scaffolding during façade installation & $\$ 261.90$ \\
\hline SS1 & $\begin{array}{l}\text { Conduct site survey, including topography, hydrology, climate, vegetation, soils, human } \\
\text { use, and human health effects }\end{array}$ & $\$ 1309.52$ \\
\hline SS2 & Provide $\$ 4$ per square meter as financial support for expanding green area of the city & $\$ 2640.00$ \\
\hline SS3 & Use the space provided by removing extra parking as common space & Technical consideration \\
\hline SS6 & Reduce light pollution & Technical consideration \\
\hline $\mathrm{MR}_{\mathrm{p} 1}$ & $\begin{array}{c}\text { Prepare storage and collection of recyclables, including plastics, glass, mixed paper, } \\
\text { corrugated cardboard, and metals }\end{array}$ & $\$ 1428.57$ \\
\hline $\mathrm{MR}_{\mathrm{p} 2}$ & Prepare waste management plan for construction phase & $\$ 1304.76$ \\
\hline MR5 & Limit construction waste to less than 12.2 kilograms per square meter & Technical consideration \\
\hline $\mathrm{EA}_{\mathrm{p} 1}$ & Hire commissioning authority $(\mathrm{CxA})$ & $\$ 6523.81$ \\
\hline $\mathrm{EA}_{\mathrm{p} 2}$ & $\begin{array}{l}\text { Conduct energy modeling, considering Applied Iranian National Building Code, Part } 19 \\
\text { (Energy Conservation) }\end{array}$ & Fulfill IP \\
\hline EA1 & $\begin{array}{c}\text { Manage and control activities related to energy, water, durability, and indoor } \\
\text { environmental quality by CxA }\end{array}$ & Fulfill $\mathrm{EA}_{\mathrm{p} 1}$ \\
\hline WE4 & Install water metering system for each unit & $\$ 1785.71$ \\
\hline $\mathrm{IQ}_{\mathrm{p} 2}$ & Prohibit smoking inside the building by installing adequate signs & $\$ 21.43$ \\
\hline IQ3 & Prepare construction indoor air quality management plan by a safety and health expert & $\$ 978.57$ \\
\hline IQ6 & Use adjustable switches with at least three lighting levels (on, off, midlevel) & $\$ 952.38$ \\
\hline IQ7 & Conduct energy modeling, including daylight simulation & Fulfill IP \\
\hline IN2 & Employ someone who is LEED Accredited Professional (AP) as advisor & $\$ 1957.14$ \\
\hline
\end{tabular}

For instance, in order to get points for the Integrative Process (IP) credit, it is necessary to model the use of energy and water besides daylight simulation. Companies that provide such a service would charge $\$ 6,850$ for the case building. Technical consideration is needed for LT6; this incurs no extra cost. The case building had already prepared 18 parking spaces in its constructed area. Decreasing the number of needed parking spaces to 15 , according to the number of apartments, makes it possible to use the free space for other purposes, e.g., a lobby. Credits SS6 and MR5 are also free of charge. There is no difference in prices in the Iranian electrical market for lighting fixtures that have limited light pollution level into the accepted level by appropriate design. In addition, limiting the amount of construction waste to less than $12.2 \mathrm{~kg} / \mathrm{m}^{2}$ needs careful and continuous waste management during the construction process. The case building had a waste management plan but without paying attention to the limitation of waste production required by LEED certification.

\subsubsection{Scenario 1: Current Situation}

Scenario 1 is equivalent to the current situation, i.e., the building without any modifications. The majority of the points in scenario 1 were earned in the Location and Transportation (LT) category $(30 \%)$. According to LEED, the building was constructed in a previously developed land located 
in a densely built area (more than $8035 \mathrm{~m}^{2}$ buildable land within a hectare with a radius of $400 \mathrm{~m}$ ), which has a supermarket, hardware store, pharmacy, bank, gym, restaurant, and a K-12 school nearby. In addition, there is a governmental office serving the public within $800 \mathrm{~m}$ from the entrance of the building. Furthermore, a bus connection is available with more than 150 connections during weekdays and 110 connections on weekends.

Among the points earned, 20\% came from the Indoor Environmental Quality (IQ) category. The Applied Iranian National Building Code (AINBC), Part 14 (mechanical systems) was adopted in the project. Other parts of AINBC that were considered dealt with electrical design, energy performance, and safety. In terms of mechanical design, the installation of the heating system (water-mounted heater) in the balconies and cooling system (evaporative cooler) on the roof helped improve the quality of the indoor environment. Enabling the use of adjustable radiators makes it possible to control the level of heat in separate spaces. Regarding electrical design, the specification of lighting fixtures was taken into account by using light sources with a color rendering index (CRI) of 80 or higher. Furthermore, the quality of views was considered in the most regularly used areas (75\%) by installing windows with colorless glass without frits, fibers, patterned glazing, or added tints that distort color balance.

The Sustainable Sites (SS) category corresponded to $17 \%$ of the total points earned by the studied building. Sedimentation and soil erosion were not relevant factors at the study location, and rainwater is infiltrated. High-reflectance material was used in the roof.

The rest of the points were earned in the categories of Energy and Atmosphere (EA, 13\%), Regional Priority (RP, 10\%), Water Efficiency (WE, 7\%), and Integrative Process (IP, 3\%) whereas no points were attainable in the Material and Resources (MR) and Innovation (IN) categories. A water metering system covering the whole building had already been installed. Besides, each of the 15 units has a natural gas and electricity metering system. The price of electricity varies from high to medium and low according to the local electricity provider. Regarding the RP category, it is necessary to pay more attention to the environmental issues. This means that at least one point should be earned for thermal comfort (EQ5), two points for heat island reduction (SS5), and two for water use reduction (WE1) outdoors in the location of the project, according to USGBD website. Each of these three elements gives one LEED point.

\subsubsection{Scenarios 2 and 3: Building with Technical Modifications}

In addition to the baseline scenario (i.e., current situation, Table 3) two scenarios were created. Scenarios 2 and 3 demonstrate how the building could attain a Certified- or Silver-level LEED certification by implementing some technical modifications and with extra cost. In addition to fulfilling the Scenario 1 conditions, Scenario 2 needs to apply credits IP, LT4, LT6, SS1, SS2, SS3, SS6, IQ3, IQ6, and IQ7 as well. These credits were selected to have lower cost compared to other remaining credits in Table 4 and are feasible for getting the points required for the Certified level. Likewise, Scenario 3 should justify all the remaining credits while passing Scenario 2 conditions.

\section{Results}

In its current format (Scenario 1), the case building located in Karaj city (Iran) can earn 29 points obtained from the LEED credits of LT1, LT3, LT4, SS4, SS5, EA3, EA4, EA6, WE2, IQ2, IQ5, IQ6, IQ8, IQ9, and RP (Table 3 and Figure 1). An additional 12 points are required in order to gain the Certified level of LEED certification. Scenario 2 illustrates how these points can be earned with the lowest possible cost (Table 4 and Figure 1). The points were selected from credits IP, LT4, LT6, SS1, SS2, SS3, SS6, IQ3, IQ6, and IQ7 (Table 4). Some of these credits require technical modifications without any extra costs. Finally, it is necessary to fulfill all technical actions that incur extra costs (Table 4) to obtain the 22 extra points needed to get the Silver level of LEED certification (Figure 1). 


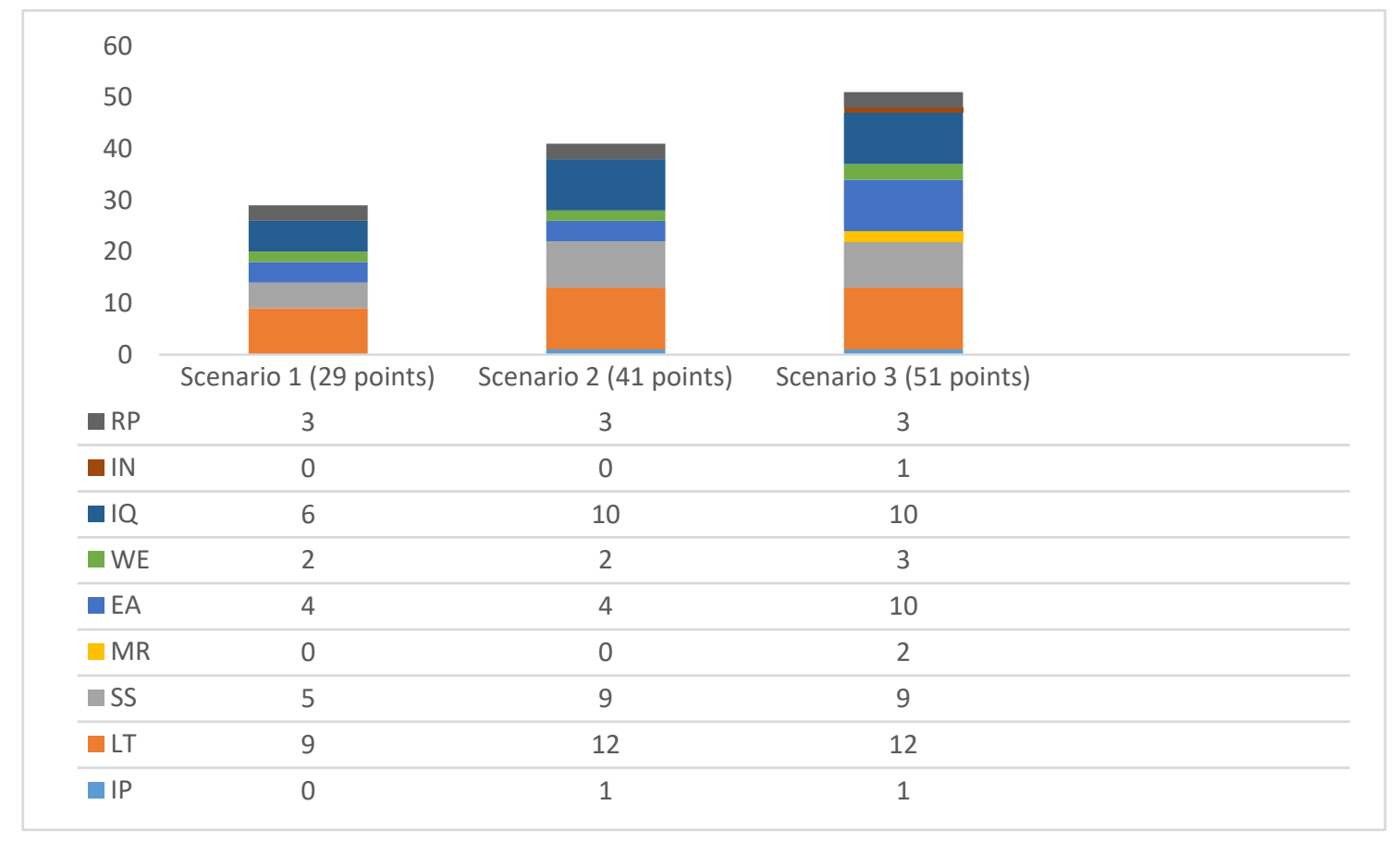

Figure 1. The number of points earned from each credit category (note: points needed for the Certified level are 40-49 and for the Silver level are 50-59).

The additional costs of gaining even the Certified-level LEED certification are noteworthy (Table 5). The LEED cost itself is divided into two parts: registration (\$1500) and certification review process (\$3420). The extra design and construction cost added to the LEED certification cost will result in total additional costs of $3.4 \%$, at the minimum. For the Silver-level LEED certification, 22 points are needed, which will result in at least $5.9 \%$ higher total costs (Table 5).

Table 5. LEED certification of the case building: cost difference between the Certified- and Silver-level certification.

\begin{tabular}{lcc}
\hline \multicolumn{1}{c}{ LEED Points and Level } & 41 Points (Certified) & 51 Points (Silver) \\
\hline Total construction cost $(\$)$ & $527,024.00$ & $527,024.00$ \\
Unit construction cost $(\$ / \mathrm{m})$ & 192.40 & 192.40 \\
LEED cost $(\$)$ & 4920.00 & 4920.00 \\
Extra design and construction cost $(\$)$ & $13,014.00$ & $26,014.00$ \\
Total LEED certification cost $(\$)$ & $17,934.00$ & $30,934.00$ \\
Unit LEED certification cost $(\$ / \mathrm{m})$ & 6.55 & 11.29 \\
Percentage of added cost $(\%)$ & 3.4 & 5.9 \\
\hline
\end{tabular}

\section{Analysis and Discussion}

\subsection{Interpretation of the Results}

This paper evaluated the possibility of getting a building LEED-certified in Iran by implementing technical modifications. It was found out that besides technical considerations, a minimum extra cost of $3.4 \%$ and $5.9 \%$ is needed in order to gain a Certified- or Silver-level LEED certification, respectively. According to the literature, the results seem to be comparable. Fuerst and Franz [29] expected an additional cost of $2 \%$ to $10 \%$, and She et al. [27] estimated the cost difference to be $4.5 \%$ to $11 \%$. Regarding the location, the study by Uğur and Leblebici [30] carried out in Turkey is the most similar to the current case study, as both Iran and Turkey have an undeveloped green building market. In the Turkish study, the extra cost of two LEED-certified buildings with Gold and Platinum level was $7.43 \%$ 
and $9.43 \%$ from the total costs. It is necessary to mention that for the case study, it was targeted to get the lowest total points for earning a Certified-level (41 points) or a Silver-level (51 points) certification, while the same level of certification is awarded to a building with 49 or 59 points, which would incur higher costs.

\subsection{Importance of Location}

In the nine LEED categories, the case study got 12 points in the category LT (Location and Transportation). Generally, fulfilling the requirements of this category is the easiest but not cheapest way of getting the points needed for certification, since 14 out of 16 points of this category can be achieved without extra cost and by just selecting a piece of land for construction located in a desirable place according to LEED. However, it is necessary to point out that preparing the land for construction might be more expensive in places that fulfill the requirements of different credits, such as access to quality transit, dense population with diverse uses, or access to bicycle facilities. Selecting the location for a construction project will also affect other credits, such as EA7 (Green Power and Carbon Offsets), because it might be possible to buy green energy in some specific parts of the city. It is probable that clean energy is available in a specific part of a city, which will motivate investors to construct the buildings in such a location.

Regarding location on a wider scale (different countries), it is worth focusing on building standards and codes in different cities or locations of a country, and comparing developed, developing, and non-developed countries. In some developed countries there are strict regulations and codes for construction, which might result in automatically getting more than 40 points, and consequently being eligible for the Certified-level LEED certification. These codes and regulations include considerations of energy, water, indoor air quality, and material usage. Furthermore, there might be access to construction materials with environmental product declarations, sourcing of raw materials, and material ingredients in some locations. This makes it possible to obtain six points from the MR2 (Environmental Product Declarations), MR3 (Sourcing of Raw Materials), and MR4 (Material Ingredients) credits.

Technology available in the location of a construction project plays a significant role in getting the necessary points for certification. There are materials and processes that need a higher level of technology and are considered obstacles to improving green construction [29]. The unavailability of technology hindered the studied building from attaining some points of the WE2 (Indoor Water Use Reduction) credit category. Six points of WE2 would be earned from the installation of water-efficient fixtures. LEED gives one to six points in the case of installed fixtures if they result in a reduction of $25 \%$ to $50 \%$ in water usage. The point here is that these new high-tech fixtures are not available for purchase in the location of the case study building. There is not even a specification from the manufacturers for how much water these fixtures use. This makes it impossible to earn all the available points.

The low price of energy in the location of the case building (Iran), including natural gas and electricity, has resulted in limited improvement in the manufacturing equipment needed for the production of renewable onsite energy. Therefore, it is very difficult to earn the available three points in the EA5 (Renewable Energy Production) credit category. There is no company in the study location with the technology and who provides installation for utilizing renewable energy resources, such as solar and wind. At the same time, the location is very favorable for producing solar energy. In addition, technology cannot improve green construction without being used by development institutes; research centers, such as universities; government; and non-governmental institutes [39].

\subsection{Factual Environmental Performance of LEED-Certified Buildings}

It is worth noting that it is possible to get a LEED certification, especially at lower levels, without gaining points in all categories. Excluding the IN (Innovation) category, it is clear that the studied building earned no points in the MR (Material and Resources) category for Certified level (see appen 1). Points in the categories LT (Location and Transportation) and SS (Sustainable sites) totales 26, and if an investor focuses on the points in the IQ (Indoor Environmental Quality) category, the Certified 
level of LEED certification is achievable. In this case, the efficiency of the building in energy and water consumption besides environmentally-friendly material usage is doubtful. A literature review paper by Amiri et al. [49] on the energy-efficiency of LEED-certified buildings revealed that the energy efficiency of LEED-certified buildings, especially at the lower (Certified) level, is questionable.

\subsection{Suggestions for LEED and Other Policy Implications}

While LEED is a good tool for the evaluation of the sustainability of buildings, it has some shortcomings. These shortcomings appear particularly when looking at the construction in different parts of the world. LEED tries to take the location of the buildings into account by allocating four extra points to the category RP (Regional Priority), but this does not solve the problem. Therefore, it is recommended to modify LEED for the purposes of different countries while simultaneously keeping in mind the international, uniform definition (to be developed) for green buildings.

In order to meet the sustainability goals of LEED, it is necessary that the U.S. Green Building Council (USGBC) makes it mandatory for projects seeking LEED certification to earn some minimum number of points in all LEED categories, except in the categories Integrative Process (IP), Innovation (IN), and Regional Priority (RP). This would guarantee that LEED-certified buildings, even in lower levels, have fewer environmental and social impacts than other new buildings on average.

For some investors, especially the private ones, the possibility of charging the added cost of changes needed for green certification requirements to clients is considered a motivator. Because of the low prices of energy and water in Iran, the willingness to pay extra money to buy buildings with lower water and energy consumption is very low. The only category that can be motivating is the indoor environmental quality. This means that external environment (political) factors play more important roles than economic and technical factors. To resolve this issue, governments or local organizations in Iran could grant awards or discounts in the permit process of construction to projects that aim at a green certification such as LEED. Giving the permission of an extra floor for a project seeking green building certification is another useful example of a motivating award. It is also necessary to consider the awareness of people and constructors' access to technology, besides environmental, social, and economic concerns in the location.

\section{Conclusions and Recommendations for Further Research}

Limited natural resources and the continuous rise of energy use by buildings makes it necessary to construct them sustainably. Leadership in Environmental and Energy Design (LEED) is one of the most famous building certifications, which tries to consider sustainability aspects in the construction of buildings. This certification might result in extra costs and so, the purpose of this study was to find out the magnitude of such extra costs added to the technical modifications needed for getting a building LEED certified in Iran.

The studied building earned 29 points out of 110 in its current format-most of these points came from the LT (Location and Transportation) credit category. Other categories, IQ (Indoor environmental Quality) and SS (Sustainable Sites), ranked second and third in the number of points earned. In order to have 12 additional points and obtain the Certified-level certification, an extra cost of $3.4 \%$ would be needed. Eligibility for the Silver level, with 51 points $(29+22)$, would require an additional investment of $5.9 \%$ of the total costs.

In general, the location of the project, available technology, level of public awareness, and green regulations play a significant role in earning the points needed for LEED certification. Among these factors, the location of the project is the easiest but not necessarily the cheapest way of getting 16 points if it is possible to select a location that is desirable from the certification perspective. The case building got nine points in the category of LT in the current location, while analyzing the extra cost of pursuing LEED certification in other locations is wealthy to consider. Some credits of the WE or MR categories are impossible to obtain in Iran because of the lack of access to LEED-specified fixtures in the WE category or the shortage of regulations in MR category. 
Considering the nine categories of LEED, when pursuing a higher level (Gold) LEED certification, it is recommended to research the EA2 (Optimize Energy Performance) credit category, which covers 18 points. It is advisable to change the thickness or material of the exterior walls, size of windows, and insulation, since these serve as a way to decrease the energy consumption and earn the needed LEED points, which were essential in the computer energy simulation of the building case study. It should be noted that this study was based on one case building so the results cannot be generalized, although the building represents a typical residential building in Iran. Therefore, more case studies on the technical and economic feasibility and environmental impacts of the most recent LEED v4 are needed, particularly in the context of developing countries, in order to increase the use and impact of green building certifications.

Author Contributions: Conceptualization, A.A., J.O. and J.S.; methodology, A.A.; validation, A.A., J.O. and J.S.; formal analysis, A.A.; investigation, A.A.; resources, A.A.; writing-original draft preparation, A.A.; writing-review and editing, A.A., J.O., J.S. and S.J.; supervision, S.J.; project administration, J.S. All authors have read and agreed to the published version of the manuscript.

Funding: This research received no external funding.

Acknowledgments: The authors thank Rah Rizan Fardis Co. for their advice and data preparation of the case study building, and Foundation for Aalto University Science and Technology for awarding the research travel grant.

Conflicts of Interest: The authors declare no conflict of interest.

\section{References}

1. Robichaud, L.B.; Anantatmula, V.S. Greening project management practices for sustainable construction. J. Manag. Eng. 2010, 27, 48-57. [CrossRef]

2. Hwang, B.; Leong, L.P.; Huh, Y. Sustainable green construction management: Schedule performance and improvement. Technol. Econ. Dev. Econ. 2013, 19, S43-S57. [CrossRef]

3. Junnila, S.; Horvath, A. Life-cycle environmental effects of an office building. J. Infrastruct. Syst. 2003, 9, 157-166. [CrossRef]

4. IPCC. Summary for Policymakers. In Global Warming of $1.5^{\circ} \mathrm{C}$. An IPCC Special Report on the Impacts of Global Warming of $1.5^{\circ} \mathrm{C}$ above Pre-Industrial Levels and Related Global Greenhouse Gas Emission Pathways, in the Context of Strengthening the Global Response to the Threat of Climate Change, Sustainable Development, and Efforts to Eradicate Poverty; Masson-Delmotte, V.P., Zhai, H.-O., Pörtner, D., Roberts, J., Skea, P.R., Shukla, A., Pirani, W., Moufouma-Okia, C., Péan, R., Pidcock, S., Eds.; Waterfield. World Meteorological Organization: Geneva, Switzerland, 2018; p. 32.

5. Schandl, H.; Fischer-Kowalski, M.; West, J.; Giljum, S.; Dittrich, M.; Eisenmenger, N.; Geschke, A.; Lieber, M.; Wieland, H.; Schaffartzik, A. Global material flows and resource productivity: Forty years of evidence. J. Ind. Ecol. 2018, 22, 827-838. [CrossRef]

6. Junnila, S.I. Empirical comparison of process and economic input-output life cycle assessment in service industries. Environ. Sci. Technol. 2006, 40, 7070-7076. [CrossRef] [PubMed]

7. Junnila, S. The Environmental Impact of an Office Building throughout Its Life Cycle; Helsinki University of Technology: Espoo, Finland, 2004.

8. Hong, H.; Wang, S.; Wu, Z.Z. Implementing sustainable management in construction industry. Adv. Mater. Res. 2011, 280, 85-88. [CrossRef]

9. Williams, K.; Dair, C. What is stopping sustainable building in England? Barriers experienced by stakeholders in delivering sustainable developments. Sustain. Dev. 2007, 15, 135-147. [CrossRef]

10. Du Plessis, C. A strategic framework for sustainable construction in developing countries. Constr. Manag. Econ. 2007, 25, 67-76. [CrossRef]

11. Shen, L.; Tam, V.W.; Tam, L.; Ji, Y. Project feasibility study: The key to successful implementation of sustainable and socially responsible construction management practice. J. Clean. Prod. 2010, 18, 254-259. [CrossRef]

12. Razieh, N.; Nicoletta, A.-V.; Hazar, D. A study of the effects of computer animation on college students' learning of Leadership in Energy and Environmental Design_LEED. Eur. Alliance Innov. 2013, 1, 1-9.

13. Gurgun, A.P.; Arditi, D. Assessment of Energy Credits in LEED-Certified Buildings Based on Certification Levels and Project Ownerships. Buildings 2018, 8, 29. [CrossRef] 
14. Ferreira, J.; Pinheiro, M.D.; de Brito, J. Portuguese sustainable construction assessment tools benchmarked with BREEAM and LEED: An energy analysis. Energy Build. 2014, 69, 451-463. [CrossRef]

15. Ryu, H.; Park, K. A study on the LEED energy simulation process using BIM. Sustainability 2016, 8, 138. [CrossRef]

16. Zhong, Z.Y.; Chen, Y.G. Principles of sustainable construction project management based on lean construction. Adv. Mater. Res. 2011, 225-226, 766-770. [CrossRef]

17. Riazi, M.; Hosseyni, S.M. Overview of current energy policy and standards in the building sector in Iran. Sustain. Dev. Plan. V 2011, 150, 189-200.

18. Pitt, M.; Tucker, M.; Riley, M.; Longden, J. Towards sustainable construction: Promotion and best practices. Constr. Innov. 2009, 9, 201-224. [CrossRef]

19. Tam, V.W.; Hao, J.L.; Zeng, S.X. What affects implementation of green buildings? An empirical study in Hong Kong. Int. J. Strateg. Prop. Manag. 2012, 16, 115-125. [CrossRef]

20. Schwartz, Y.; Raslan, R. Variations in results of building energy simulation tools, and their impact on BREEAM and LEED ratings: A case study. Energy Build. 2013, 62, 350-359. [CrossRef]

21. Yudelson, J. The Green Building Revolution; Island Press: Denver, CO, USA, 2010.

22. Kibert, C.J. Sustainable Construction: Green Building Design and Delivery; John Wiley \& Sons: Hoboken, NJ, USA, 2016.

23. Al-Ghamdi, S.G.; Bilec, M.M. Life-cycle thinking and the LEED rating system: Global perspective on building energy use and environmental impacts. Environ. Sci. Technol. 2015, 49, 4048-4056. [CrossRef]

24. Moore, S.; Rydin, Y. Promoting sustainable construction: European and British networks at the knowledge-policy interface. J. Environ. Policy Plan. 2008, 10, 233-254. [CrossRef]

25. Musa, M.F.; Mohammad, M.F.; Mahbub, R.; Yusof, M.R. Enhancing the quality of life by adopting sustainable modular industrialised building system (IBS) in the Malaysian construction industry. Procedia-Soc. Behav. Sci. 2014, 153, 79-89. [CrossRef]

26. Komurlu, R.; Arditi, D.; Gurgun, A.P. Applicability of LEED's energy and atmosphere category in three developing countries. Energy Build 2014, 84, 690-697. [CrossRef]

27. Lee, W.L.; Burnett, J. Benchmarking energy use assessment of HK-BEAM, BREEAM and LEED. Build. Environ. 2008, 43, 1882-1891. [CrossRef]

28. Nilson, M.L. Quantifying the Cost Impacts of LEED-NC Gold Construction in New York City. Senior Honor Thesis, Department of Civil and Environmental Engineering, Lafayette College, Easton, PA, USA, 2005.

29. Pearce, D. Is the construction sector sustainable? Definitions and reflections. Build. Res. Inf. 2006, 34, $201-207$. [CrossRef]

30. Jeong, J.; Hong, T.; Ji, C.; Kim, J.; Lee, M.; Jeong, K. Development of an evaluation process for green and non-green buildings focused on energy performance of G-SEED and LEED. Build. Environ. 2016, 105, 172-184. [CrossRef]

31. Donghwan, G.; Yong, K.H.; Hyoungsub, K. LEED, its efficacy in regional context: Finding a relationship between regional measurements and urban temperature. Energy Build. 2015, 86, 687-691. [CrossRef]

32. Zhao, J.; Lam, K.P.; Biswas, T.; Wang, H. An online platform to automate LEED energy performance evaluation and submission process. Constr. Innov. 2015, 15, 313-332. [CrossRef]

33. USGBC. Available online: https://new.usgbc.org/ (accessed on 15 March 2019).

34. Vyas, G.S.; Jha, K.N. What does it cost to convert a non-rated building into a green building? Sustain. Cities Soc. 2018, 36, 107-115. [CrossRef]

35. Burnett, J. Sustainability and sustainable buildings. HKIE Trans. 2007, 14, 1-9. [CrossRef]

36. Shen, L.; Li Hao, J.; Tam, V.W.; Yao, H. A checklist for assessing sustainability performance of construction projects. J. Civ. Eng. Manag. 2007, 13, 273-281. [CrossRef]

37. Poveda, C.A.; Young, R. Potential benefits of developing and implementing environmental and sustainability rating systems: Making the case for the need of diversification. Int. J. Sustain. Built Environ. 2015, 4, 1-11. [CrossRef]

38. Green Building Cost and Financial Benefits. Available online: http://www.greenspacebuildings.com/wpcontent/uploads/2011/05/Kats-Green-Buildings-Cost.pdf (accessed on 22 November 2018).

39. Kats, G.; Alevantis, L.; Berman, A.; Mills, E.; Perlman, J. The Costs and Financial Benefits of Green Buildings: A Report to California's Sustainable Building Task Force; Health Care without Harm: Reston, VA, USA, 2003. 
40. She, Y.J.; Zhu, Y.H.; Huang, Q. System of sustainable construction based on project whole life cycle management. Adv. Mater. Res. 2012, 403-408, 2093-2097. [CrossRef]

41. Fuerst, F. Building momentum: An analysis of investment trends in LEED and Energy Star-certified properties. J. Retail Leis. Prop. 2009, 8, 285-297. [CrossRef]

42. Fuerst, F.; McAllister, P. Eco-labeling in commercial office markets: Do LEED and Energy Star offices obtain multiple premiums? Ecol. Econ. 2011, 70, 1220-1230. [CrossRef]

43. Matthiessen, L.F.; Morris, P. Cost of Green Revisited: Reexamining the Feasibility and Cost Impact of Sustainable Design in the Light of Increased Market Adoption; Continental Automated Buildings Association: Los Angeles, CA, USA, 2007.

44. Matthiessen, L.F.; Morris, P.; Georges, D. Costing Green: A Comprehensive Cost Database and Budgeting Methodology by Lisa Fay Matthiessen and Peter Morris; Davis Landon Adamson: Los Angeles, CA, USA, 2004.

45. Sabapathy, A.; Ragavan, S.K.; Vijendra, M.; Nataraja, A.G. Energy efficiency benchmarks and the performance of LEED rated buildings for Information Technology facilities in Bangalore, India. Energy Build. 2010, 42, 2206-2212. [CrossRef]

46. Managing the Cost of Green Building. Available online: https://www. google.fi/url? sa $=$ t\&rct=j\&q=\&esrc $=$ s\&source $=$ web $\& c d=1 \&$ cad $=$ rja\&uact $=8 \& v e d=$ 2ahUKEwjU-5aO96rmAhXHwsQBHUy3BOEQFjAAegQIAxAC\&url=https\%3A\%2F\%2Fwww. calrecycle.ca.gov\%2Fdocs\%2Fcr\%2Fgreenbuilding\%2Fdesign\%2Fmanagingcost.pdf\&usg= AOvVaw0FuAY4O4kQ9fJ46qlHljFW (accessed on 5 December 2019).

47. Uğur, L.O.; Leblebici, N. An examination of the LEED green building certification system in terms of construction costs. Renew. Sustain. Energy Rev. 2018, 81, 1476-1483. [CrossRef]

48. Mapp, C.; Nobe, M.; Dunbar, B. The cost of LEED-An analysis of the construction costs of LEED and non-LEED banks. J. Sustain. Real Estate 2011, 3, 254-273.

49. Amiri, A.; Ottelin, J.; Sorvari, J. Are LEED-Certified Buildings Energy-Efficient in Practice? Sustainability 2019, 11, 1672. [CrossRef]

50. Building Steel Structure. Available online: http://www.abadsazeh-moradi.blogfa.com/ (accessed on 10 December 2019).

(C) 2020 by the authors. Licensee MDPI, Basel, Switzerland. This article is an open access article distributed under the terms and conditions of the Creative Commons Attribution (CC BY) license (http://creativecommons.org/licenses/by/4.0/). 